\title{
Pathology of Tangier disease
}

\author{
PATRICIA M. BALE, P. CLIfTON-BLigh, B. N. P. BENJAMIN, AND H. M. WhYTE \\ From the Institute of Pathology, Royal Alexandra Hospital for Children, Camperdown, Sydney, and the \\ Department of Clinical Science, Australian National University, Canberra
}

SYNOPSIS Two cases of Tangier disease are described in children from families unrelated to each other. Necropsy in one case, the first to be reported in this condition, showed large collections of cholesterol-laden macrophages in tonsils, thymus, lymph nodes, and colon, and moderate numbers in pyelonephritic scars and ureter. As the storage cells may be scanty in marrow, jejunum, and liver, the rectum is suggested as the site of choice for biopsy.

The diagnosis was confirmed by demonstrating the absence of $\alpha$-lipoproteins from the plasma of the living child, and by finding low plasma levels in both parents of both cases. The disease can be distinguished from other lipidoses by differences in the predominant sites of storage, staining reactions, and serum lipid studies.

Tangier disease is a familial storage disorder in which esterified cholesterol accumulates in macrophages, while plasma cholesterol is low, and plasma high density lipoprotein is virtually absent.

Ten cases have been reported, and we have studied two additional patients, one of whom is the first Received for publication 27 November 1970. necropsied case. The 12 subjects (Table I) have come from eight families, the first of which lived on Tangier Island, Chesapeake Bay, Virginia. Males and females have been equally represented, and affected relatives have always been siblings, never parent and child, suggesting an autosomal recessive inheritance. Consanguinity has been recorded in the

\begin{tabular}{|c|c|c|c|c|c|c|c|c|c|c|c|}
\hline Author & Family & $\begin{array}{l}\text { Sex } \\
\text { Age }\end{array}$ & & Tonsils & $\begin{array}{l}\text { Spleno- } \\
\text { megaly }\end{array}$ & $\begin{array}{l}\text { Neuro- } \\
\text { pathy }\end{array}$ & $\begin{array}{l}\text { Rectal } \\
\text { Storage }\end{array}$ & $\begin{array}{l}\text { Marrow } \\
\text { Storage }\end{array}$ & Cornea & $\begin{array}{l}\text { Plasma } \\
\text { Cholesterol } \\
(\mathrm{mg} / 100 \mathrm{ml})\end{array}$ & $\begin{array}{l}H D L^{1} \\
\text { Cholesterol } \\
(\mathrm{mg} / 100 \mathrm{ml})\end{array}$ \\
\hline $\begin{array}{l}\text { Fredrickson, Altrocchi, } \\
\text { Avioli, Goodman, \& }\end{array}$ & 1 & $\mathbf{M}$ & 5 & + & $\begin{array}{r}+ \text { hepato- } \\
\text { megaly }\end{array}$ & - & - & \pm & - & 54 & 1 \\
\hline Goodman (1961) & & $\mathbf{F}$ & 7 & + & - & - & - & \pm & - & 85 & $\mathbf{0}$ \\
\hline $\begin{array}{l}\text { Fredrickson (1964) } \\
\text { Fredrickson (1966) }\end{array}$ & 2 & $\begin{array}{l}\mathbf{F} \\
\mathbf{F}\end{array}$ & $\begin{array}{l}12 \\
8\end{array}$ & $\begin{array}{l}+ \\
+\end{array}$ & + & $\overline{-}$ & - & $\begin{array}{l}\cdots \\
\cdots\end{array}$ & - & $\begin{array}{r}76 \\
117\end{array}$ & $\begin{array}{l}\mathbf{0} \\
\mathbf{0}\end{array}$ \\
\hline $\begin{array}{l}\text { Hoffman \& Frederickson } \\
\text { (1965) }\end{array}$ & 3 & $\begin{array}{l}\mathbf{M} \\
\mathbf{M}\end{array}$ & $\begin{array}{l}42 \\
48\end{array}$ & $\begin{array}{l}\text { + removed } \\
\text { +removed }\end{array}$ & + & $\begin{array}{l}- \\
-\end{array}$ & \multicolumn{2}{|c|}{+ diarrhoea +} & $\begin{array}{l}+ \\
+\end{array}$ & $\begin{array}{r}125 \\
50\end{array}$ & $\begin{array}{l}1 \\
2\end{array}$ \\
\hline $\begin{array}{l}\text { Kocen, Lloyd, Lascelles, } \\
\text { Fosbrooke, \& Williams } \\
\text { (1967) }\end{array}$ & 4 & $\mathbf{M}$ & 37 & ..removed & + & + & + & + & - & 50 & 8 \\
\hline $\begin{array}{l}\text { Engel, Dorman, Levy, } \\
\text { \& Fredrickson (1967) }\end{array}$ & 5 & $\begin{array}{l}\mathbf{F} \\
\mathbf{F}\end{array}$ & $\begin{array}{l}16 \\
24\end{array}$ & $\begin{array}{l}\text { +removed } \\
\ldots\end{array}$ & $\begin{array}{l}+ \\
\cdots\end{array}$ & $\begin{array}{l}+ \\
+\end{array}$ & +diarrhoea. & + & $\overline{+}$ & $\begin{array}{l}68 \\
84\end{array}$ & $\begin{array}{l}0 \\
0\end{array}$ \\
\hline $\begin{array}{l}\text { Kummer, Laissue, Spiess, } \\
\text { Pflugshaupt, \& Bucher } \\
\text { (1968) }\end{array}$ & 6 & $\mathbf{M}$ & 40 & + & $\begin{array}{r}+ \text { hepato- } \\
\text { megaly }\end{array}$ & \pm & \pm & + & + & 39 & $1 \cdot 8$ \\
\hline $\begin{array}{l}\text { Bale, Clifton-Bligh, } \\
\text { Benjamin, \& Whyte. }\end{array}$ & $\begin{array}{l}7 \\
8\end{array}$ & $\begin{array}{l}\mathbf{M} \\
\mathbf{F}\end{array}$ & $\begin{array}{l}5 \\
6\end{array}$ & $\begin{array}{l}+ \\
+ \text { removed }\end{array}$ & $\begin{array}{l}- \\
-\end{array}$ & $\overline{-}$ & $\begin{array}{l}+ \\
\cdots\end{array}$ & $\begin{array}{l}- \\
\cdots\end{array}$ & - & $\ddot{67}$ & $\ddot{7}$ \\
\hline
\end{tabular}

Table I Cases of Tangier disease

${ }^{1} \mathrm{HDL}$ High density lipoprotein. 
first and third families. Six patients were diagnosed in childhood, and the other six between 16 and 48 years. Children have usually been well except for large tonsils with striking yellow streaks, and four of five patients whose tonsils had been removed had bright yellow pharyngeal plaques. Some patients have had mild splenomegaly but hepatomegaly has been less common. Three adults presented with peripheral neuropathy, two had intermittent diarrhoea, and five had storage cells in fixed marrow aspirates. Four of the older patients had cloudy corneas.

Total plasma cholesterol has always been low, varying from 39 to $125 \mathrm{mg} / 100 \mathrm{ml}$. This relates to absence or near-absence of $\alpha_{1}$-lipoproteins or high density lipoproteins, as shown by paper and immunoelectrophoresis and ultracentrifugation. Whereas the normal values for cholesterol carried in high density lipoproteins are $48.0 \pm 11.2 \mathrm{mg} / 100 \mathrm{ml}$ in males and 56.7 \pm 13.7 in females (Fredrickson, 1964) the levels in Tangier patients have been less than $10 \mathrm{mg} / 100 \mathrm{ml}$. Parents of propositi are thought to be heterozygous carriers and nearly always have abnormally low levels of high density lipoproteins, that is, less than $33 \mathrm{mg} / 100 \mathrm{ml}$ in males and 35 in females (Fredrickson, 1964, 1966).

\section{Case Reports}

\section{CASE 1}

R.W., a 5-year-old boy, was diagnosed as having cerebral birth trauma when blood was aspirated from the subdural and ventricular cavities the day after birth. He was thereafter severely retarded and spastic, and never able to stand or to talk. At the age of $2 \frac{1}{2}$ years he had enlarged tonsils with 'pus in the crypts', and at 5 years he had an attack of tonsillitis when Streptococcus pyogenes and Staphylococcus aureus were cultured from a throat swab. After numerous admissions to hospital for problems such as pyelonephritis and fits, he died with bronchopneumonia at the age of $5 \frac{3}{4}$ years. Necropsy revealed brain abnormalities including a large porencephalic cyst, and Tangier disease was an incidental postmortem finding.

\section{CASE 2}

C.S., a $6 \frac{1}{2}$-year-old girl, from a family unrelated to case 1 , had her tonsils and adenoids removed at the age of $2 \frac{1}{2}$ years. Excessive bleeding resulted, necessitating a second anaesthetic to 'tie off numerous vessels'. Tachycardia and fever developed, bruises were noted on the legs, and the mother said the child had bruised easily in the past. The day after tonsillectomy the haemoglobin level was $11.0 \mathrm{~g} / 100 \mathrm{ml}$, the platelet count was $108,000 / \mathrm{cmm}$, the bleeding time was $2 \frac{1}{2}$ minutes, the clotting time 6 minutes, and $\frac{\overrightarrow{0}}{\vec{\sigma}}$ the spleen was just palpable. Three hundred $\mathrm{ml}$ whole blood was transfused. The tonsils were not $\overrightarrow{\bar{F}}$ examined histologically. Six weeks later platelets $\overrightarrow{0}$ were 'numerous', bleeding and clotting times were $\frac{c}{0}$ still normal, and the prothrombin index was 100 . Erythrocyte sedimentation rate, serum bilirubin, $\overparen{\otimes}$ thymol turbidity, and flocculation tests were normal. The liver and lymph nodes were not enlarged.

At the age of $6 \frac{1}{2}$ years the girl presented with re- $\overrightarrow{0}$ current deafness with Eustachian tube dysfunction. $\vec{A}$ The pharynx showed residual firm yellow tissue, the removal of which was again attended by unusual bleeding. She was found at this stage to have Tangier disease. There was no anaemia, platelets $\AA$ were 'numerous', heart and optic fundi were normal, -2 ' and the spleen was palpable. Now eight years later, 8 at the age of 15 years, the girl is well apart fromo occasional minor nose bleeds, but her platelet count ${ }_{3}$. is only 80,000 (confirmed on two occasions and by $\vec{O}$ blood film) and thromboplastin generation is only $56 \%$ of normal. The Hess test, the thrombin clotting time, and plasma fibrinogen concentration are normal. $\stackrel{\mathbb{S}}{-}$ Menstrual bleeding is normal. Small orange-yellow $\vec{\varphi}$ raised areas are present on the pharynx. There is $a-$ high arched palate. Neither the spleen nor the liver are palpable and there is no lymphadenopathy. NoO cardiac murmurs are present. No abnormalities are to be seen in the cornea or ocular fundus. Urinalysis is clear. No adrenal calcification can be $\frac{\varnothing}{\varnothing}$ seen in a plain abdominal radiograph. The patient $\varrho$ has no diarrhoea, and proctoscopy was not done.

\section{Pathological Findings}

CASE 1

At necropsy, striking bright yellow streaks were seen in the enlarged tonsils, in thymus, and in mildly 3 . enlarged and normal-sized lymph nodes from the neck, mediastinum, and abdomen. The ileum, colon, $३$ and rectum showed numerous mucosal elevations, $ㅇ$ 1-2 mm diameter, of which the cut surfaces were yellow. The jejunum was normal. Mitral and tricuspid을. valves had bright yellow patches, but there was no lipid streaking of aorta or coronary arteries. Thereo were numerous bright yellow streaks in broadN cortical scars in the mildly hydronephrotic kidneys, in pelves and ureters, and a few in the subpleural $\sigma$ regions of the infected lungs. The gallbladder showed sterolosis. The liver and spleen were not enlarged, the adrenal glands were not calcified, andọ? there were no skin lesions.

Microscopically, all yellow areas showed collec- $-\frac{0}{0}$ tions of large very pale macrophages, which were most numerous in tonsils, lymph nodes, thymus, and官 colonic and rectal mucosa. In tonsils and lymph 


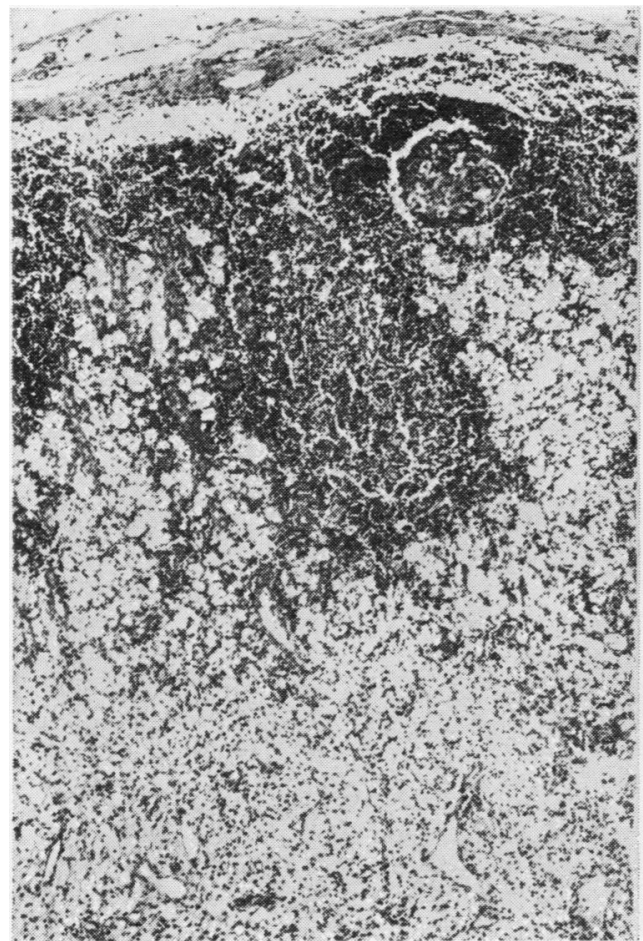

Fig. 1.

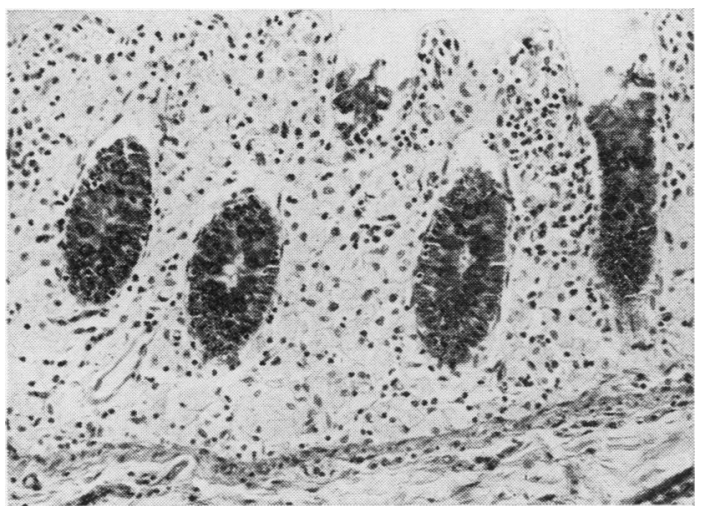

Fig. 3.

nodes the pale cells were distributed in broad bands outside the lymphoid follicles (Fig. 1), and in the thymus they were closely packed, almost replasing the cortex of the lobules, and were less numerous in the medulla (Fig. 2). In colon and rectum they completely filled the lamina propria (Fig. 3). Moderate numbers of macrophages were found in gallbladder mucosa, in ureter immediately beneath the mucosa, and in renal pyelonephritic scars, though not in

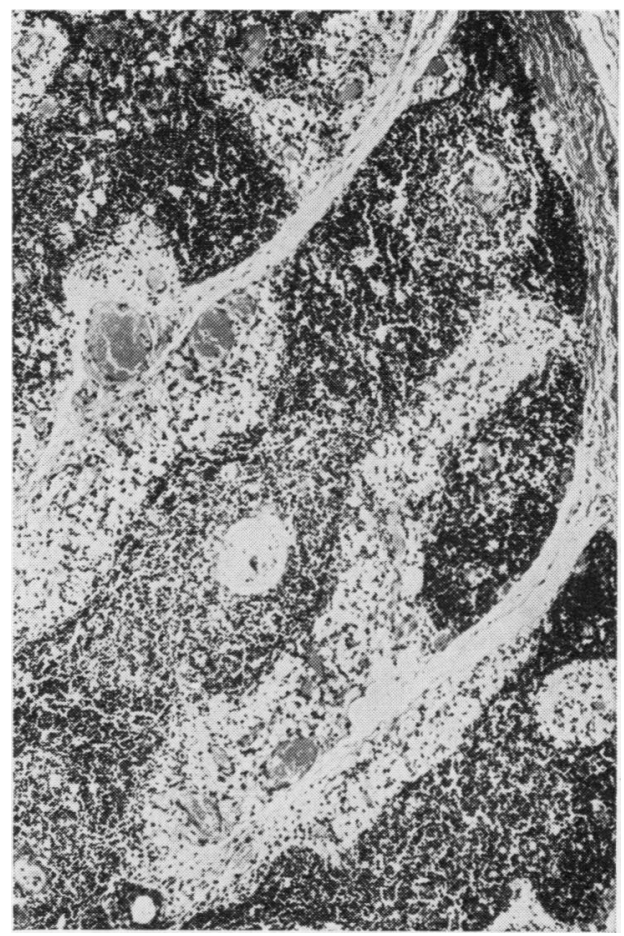

Fig. 2.

Fig. 1 Case 1: cervical lymph node. Distribution of pale macrophages predominantly in medulla $(H \& E \times$ 65).

Fig. 2 Case 1: thymus. Bands of macrophages predominantly in cortex $(H \& E \times 69)$.

Fig. 3 Case 1: colonic mucosa. Pale macrophages completely filling the lamina propria $(P A S \times 120)$.

glomeruli. In liver and spleen there were only a few pale macrophages, and none were found in bone marrow. In jejunum the storage cells were almost limited to the submucosa, directly beneath the muscularis mucosae and at the base of lymphoid patches (Fig. 4). A random block of skin revealed a few pale macrophages around dermal capillaries and small nerves, but not around larger subcutaneous nerves. Patchy semi-myxoid fibrous thickening was found in 


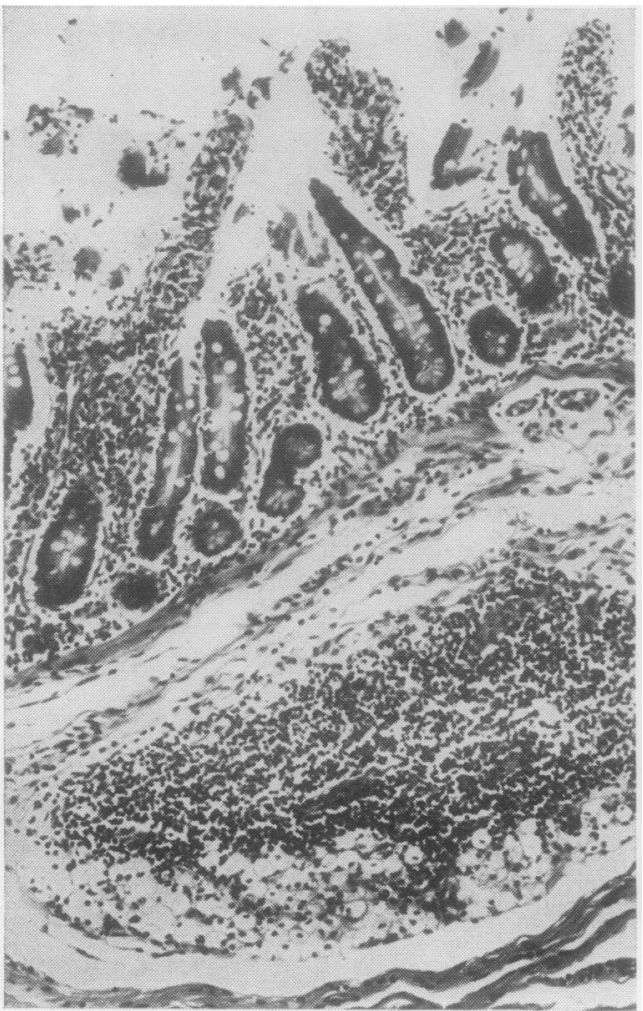

Fig. 4.

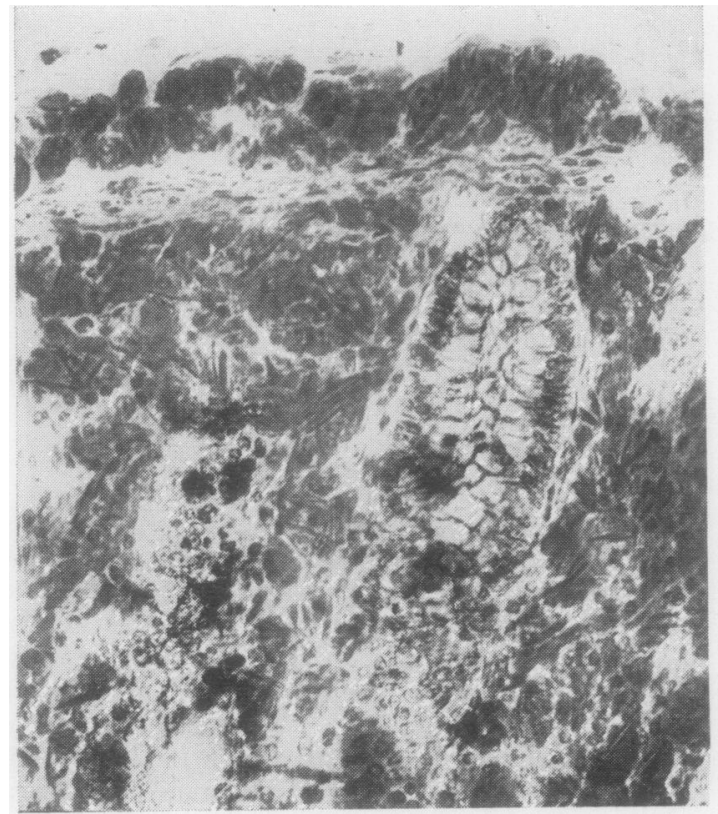

Fig. 6.

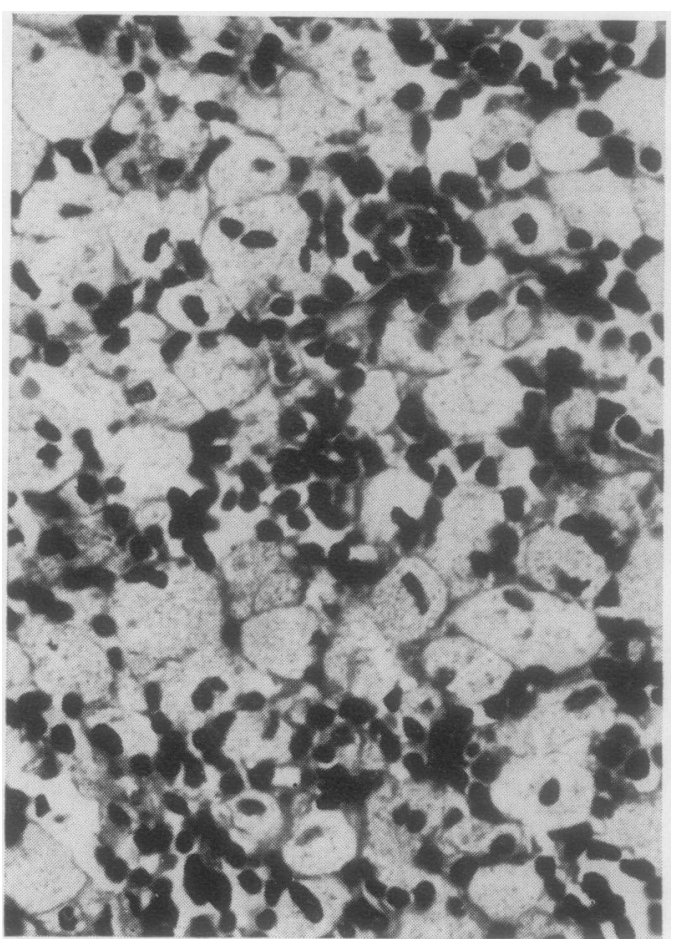

Fig. 5.

Fig. 4 Case 1: jejunum. Macrophages in submucosa beneath lymphoid patch. Normal villous cores ( $H \& E$ $\times 112)$.

Fig. 5 Case 1: tonsil. The macrophages are very finely granular rather than vacuolated $(H \& E \times 580)$.

Fig. 6 Case 1: colonic mucosa. Frozen section revealing intracellular crystals without polarized light (Sudan IV $\times 236)$.

옴

a few of the blocks of coronary arteries, so that in a $N$ vessel of $0.1 \mathrm{~cm}$ diameter, the intima was as thick as N the media.

With haematoxylin and eosin stains the macrophages appeared almost empty, but most were very $\stackrel{0}{-}$ finely granular rather than vacuolated (Fig. 5), so that 'foamy' is not an accurate description.

Sudan IV and Sudan black stains on frozen sec- $\frac{T}{D}$ tions were strongly positive in all macrophage areas, $\stackrel{\vec{\Phi}}{\vec{D}}$ and polarized light revealed that most of the intra- $\frac{\rho}{\Phi}$ cellular lipid was in the form of anisotropic rhomboid 0 
and acicular crystals (Fig. 6). The Schultz reaction for cholesterol was positive, resulting in a strong blue green colour which lasted at least four hours. Osmic acid stains on frozen sections and Alcian blue stains were negative. Periodic acid-Schiff (PAS) stains were negative (F1g. 3), except for a few very fine granules in some thymic and tonsillar storage cells. Sudan staining demonstrated that not all the lipid was in macrophages. In atrioventricular valve and tunica albuginea much of it was in loose myxoid connective tissue, and in lymphoid germ centres and jejunal villous cores there were small free Sudanpositive granules. The hepatic parenchymal cells were Sudan negative.

No storage was found in the central nervous system in either macrophages or neurones. There were macrophages in atrophic gyri around the porencephalic cyst, but these contained haemosiderin and were negative when stained with Sudan IV.

No inflammatory reaction was found in any macrophage area except in the pyelonephritic scars.

\section{CASE 2}

The residual adenoidal and tonsillar tissue, removed at the age of $6 \frac{1}{2}$ years, showed extensive collections of large, very pale macrophages between normal lymphoid follicles (Fig. 7). There was no inflammatory infiltrate or granulomatous reaction, and eosinophils were rare.

\section{Biochemical and Family Studies}

\section{CASE 1}

As the disease was unsuspected during life, lipoprotein studies were not performed on R.W., but these were later undertaken on his family (Table II). Fractionation by ultracentrifugation showed that the father and mother both had low levels of high density lipoprotein cholesterol: 20 and $13 \mathrm{mg} / 100 \mathrm{ml}$. Their fasting total plasma cholesterol was normal or low normal. The only sibling, a girl aged 4 years, and the only living grandparent, had normal levels of plasma cholesterol, with normal proportions in the high density, low density, and very low density fractions. Electrophoretic studies were not done.

The other three grandparents all died at 55-65 years of cardiovascular disease. There was no known consanguinity. Both parents had their tonsils removed in childhood, and have no yellow patches in the pharynx. The sister's tonsils were devoid of storage cells.

CASE 2

The plasma cholesterol level in the propositus was low $(59 \mathrm{mg} / 100 \mathrm{ml})$ and the triglyceride level was high $(136 \mathrm{mg} / 100 \mathrm{ml})$ (Table II). Only $7 \mathrm{mg}$ of cholesterol per $100 \mathrm{ml}$ of plasma was carried in the high density lipoproteins. No $\alpha_{1}$-lipoprotein was detected by immunodiffusion or by zonal electro-

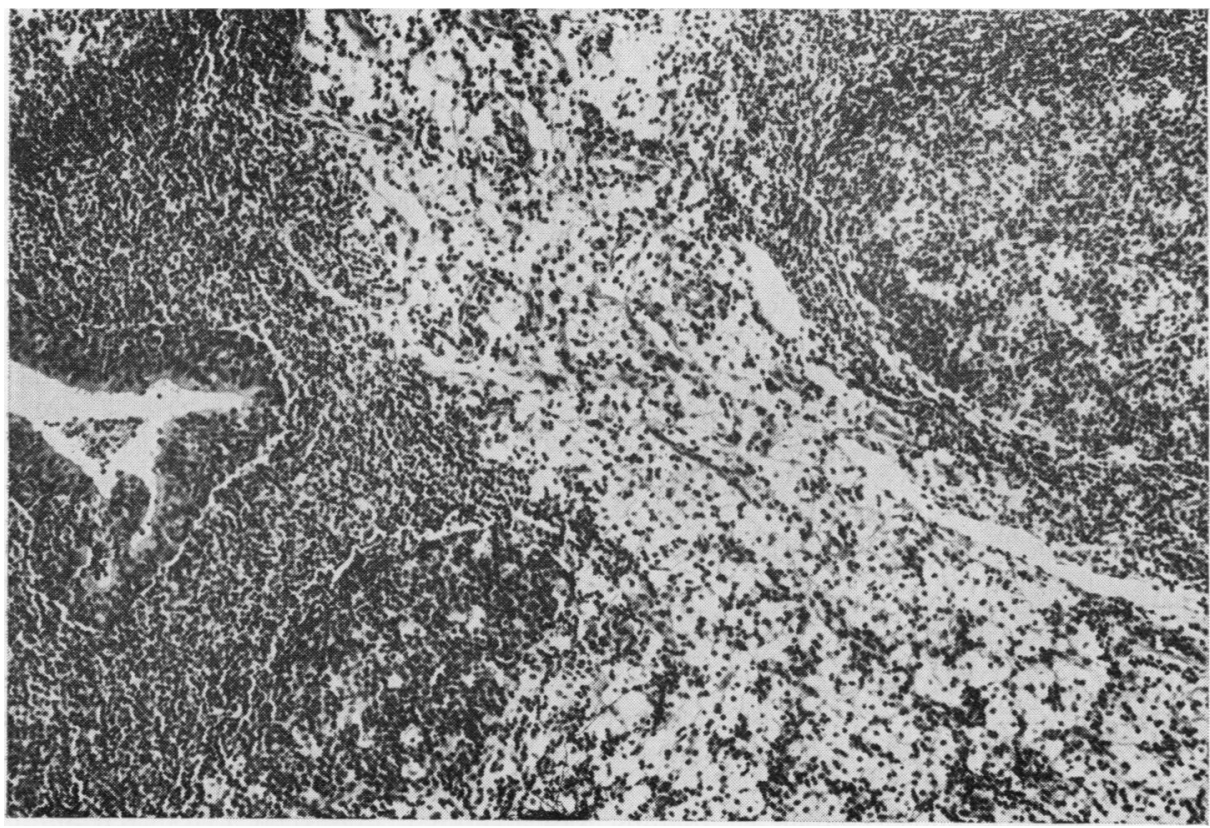

Fig. 7 Case 2: adenoid. Distribution of macrophages in central pulp, sparing lymphoid follicles $(H \& E$ $\times 109)$. 


\begin{tabular}{|c|c|c|c|c|c|c|c|c|c|c|c|}
\hline \multirow[t]{3}{*}{ Case: } & \multirow[t]{3}{*}{ Relationship } & & \multirow[t]{3}{*}{ Age } & \multicolumn{4}{|c|}{ Cholesterol Content ( $\mathrm{mg} / 100 \mathrm{ml}$ plasma) } & \multicolumn{4}{|c|}{ Triglyceride Content $(\mathrm{mg} / 100 \mathrm{ml}$ plasma) } \\
\hline & & & & \multicolumn{4}{|c|}{ Lipoprotein Density } & \multicolumn{4}{|c|}{ Lipoprotein Density } \\
\hline & & & & Total & High & Low & Very Low & Total & High & Low & Very Low \\
\hline 1 & $\begin{array}{l}\text { Father } \\
\text { Mother } \\
\text { Sister } \\
\text { Grandfather }\end{array}$ & $\begin{array}{l}\text { L.W. } \\
\text { H.W. } \\
\text { J.W. } \\
\text { I.T. }\end{array}$ & $\begin{array}{r}35 \\
33 \\
4 \\
66\end{array}$ & $\begin{array}{l}182 \\
160 \\
196 \\
239\end{array}$ & $\begin{array}{l}20 \\
13 \\
39 \\
43\end{array}$ & $\begin{array}{l}132 \\
124 \\
142 \\
160\end{array}$ & $\begin{array}{l}30 \\
23 \\
14 \\
36\end{array}$ & $\begin{array}{r}86 \\
105 \\
66 \\
126\end{array}$ & $\begin{array}{l}9 \\
4 \\
4 \\
7\end{array}$ & $\begin{array}{l}11 \\
12 \\
13 \\
30\end{array}$ & $\begin{array}{l}66 \\
89 \\
49 \\
89\end{array}$ \\
\hline 2 & $\begin{array}{l}\text { Father } \\
\text { Mother } \\
\text { Propositus }\end{array}$ & $\begin{array}{l}\text { W.S. } \\
\text { R.S. } \\
\text { C.S. }\end{array}$ & $\begin{array}{l}47 \\
38 \\
15\end{array}$ & $\begin{array}{r}167 \\
200 \\
59\end{array}$ & $\begin{array}{r}31 \\
26 \\
7\end{array}$ & $\begin{array}{r}113 \\
151 \\
47\end{array}$ & $\begin{array}{r}23 \\
23 \\
5\end{array}$ & $\begin{array}{r}86 \\
88 \\
136\end{array}$ & $\begin{array}{r}14 \\
37 \\
7\end{array}$ & $\begin{array}{l}30 \\
12 \\
49\end{array}$ & $\begin{array}{l}42 \\
39 \\
80\end{array}$ \\
\hline \multicolumn{3}{|c|}{ Control (male) } & 31 & 166 & 60 & 98 & 8 & 56 & 16 & 23 & 17 \\
\hline
\end{tabular}

Table II Cholesterol and triglyceride content of lipoproteins ${ }^{1}$

${ }^{1}$ Lipoproteins were prepared by the method of Fredrickson, Levy, and Lindgren (1968) using preparative ultracentrifugation. Blood was collscted in the morning from subjects who had been fasted overnight.

phoresis on agarose. Nor was there any pre-beta band. Both parents had lower than normal amounts of cholesterol in high density lipoproteins, 31 and $26 \mathrm{mg} / 100 \mathrm{ml}$, and showed the presence of $\alpha_{1}$-lipoproteins as a precipitation line by immunodiffusion and as a faint band in the electrophoretogram. Although there is no definite knowledge of consanguinity, the maiden name of the maternal grandmother was the same as the surname of the propositus.

\section{Discussion}

Both our patients, like all those for whom relevant data were given, showed large yellow-streaked tonsils or orange-yellow pharyngeal plaques, with intense accumulation of pale cholesterol-laden macrophages. In case 1 other prominent sites of storage were thymus, lymph nodes, and large intestinal mucosa, each of which has been recorded at least once before. Some areas of cholesterol accumulation, such as the kidney and tonsil, were sites of previous inflammation, and others such as colon and lymph nodes, may well have been so.

As the histopathologist is most likely to encounter Tangier disease in tonsils and adenoids the question of whether the macrophage accumulations indicate systemic disease or simply residua of local inflammation is the first to be decided. In our cases the collections of storage cells ramified diffusely through the pharyngeal tissue instead of forming the focal aggregates seen at the site of an old abscess or crypt cyst. However, in doubtful cases blood chemistry will be necessary, and the xanthomatous deposits of hypercholesterolaemia will immediately be excluded by the invariably low serum cholesterol found in Tangier disease.

If the storage cells are discovered in tissues other than pharynx, many diseases must be considered and more information will be required. Thus Wolman's disease is similar to Tangier disease in that there is prominent cholesterol storage in lymphoid tissues and intestinal mucosa (Wolman, Sterk, Gatt, and Frenkel, 1961), and plasma cholesterol levels may bes slightly lowered (Lough, Fawcett, and Wiegensberg. 1970). However, the distinctive features of Wolman's disease are heavily calcified adrenal glands, severe hepatosplenomegaly, and death in early childhood. In the single case on our files, many of the colonic and thymic macrophages take up more eosin and doo not appear as uniformly pale as those in Tangiers disease.

In Niemann-Pick disease there is far greate hepatosplenomegaly than in Tangier disease, and the cells do not stain uniformly strongly with Sudan IV $\overrightarrow{\widehat{O}}$ stains. Lesions of Hand-Schuller-Christian disease affect bone and usually contain numerous eosino phils.

In the rare familial cholesterol ester storage disease of Schiff, Schubert, McAdams, Spiegel, and O'Donnell (1968) foam cells may be found in jejunum, but they are in the villous cores rather than confined to the submucosa (Partin and Schubert 1969), and the hepatic storage is in parenchymal cells instead of macrophages.

In lymph nodes lipid-laden histiocytes are a charace teristic feature of certain recently described benign massive cervical lymphadenopathies (Rosai ands Dorfman, 1969), especially in the tropics (Destombes, 1965; Marie, Bernard, Nezelof, Lévêque, Schaison Desbois, Watchi, and Lemaigre-Voreaux, 1966), buf́ these show a pleomorphic inflammatory infiltrate in addition. In the cases of Rosai and Dorfman, plasma lipid studies are not mentioned.

Some other conditions may bear a superficia! resemblance to Tangier disease, but can usually be excluded by critical microscopy and special stains $\mathbb{\mathbb { D }}$ Thus in infantile Gaucher's disease the cells are more्ष opaque and wrinkled, and their cytoplasm stains 
green with Masson's trichrome. Generalized gangliosidosis (familial neurovisceral lipidosis) (Landing, Silverman, Craig, Jacoby, Lahey, and Chadwick, 1964), unlike Tangier disease, shows cells which stain positively with PAS and Alcian blue as well as with Sudan stains. PAS-positive material is usual also in the few cases of unidentified benign reticuloendothelial storage disease (Holland, Hug, and Schubert, 1965), so that most of them are unlikely to be unrecognized cases of Tangier disease.

It should be recalled that in colon mucosa and thymus diffuse foam cells are a not uncommon finding of uncertain significance, but such rectal macrophages, unlike Tangier cells, almost invariably stain positively with PAS (Yunis and Sherman, 1970).

In some cases the question of Tangier disease arises from the discovery of plasma lipid changes. A very low plasma cholesterol accompanied by virtually absent high density lipoproteins would appear to be diagnostic, but neither is pathognomonic by itself. Marked hypocholesterolaemia is also characteristic of abetalipoproteinaemia, in which there is decreased absorption of dietary lipids, and jejunal storage is limited to the surface epithelial cells (Lloyd, 1969). Similarly, the absence of $\alpha$-lipoprotein has been reported in a family with serum cholesterol ester deficiency (Gjone and Norum, 1968) but these patients had raised levels of total plasma cholesterol, with abnormally little in the esterified form. They had normal tonsils, and their predominant signs were anaemia, proteinuria, and marked corneal opacities.

Tissue assays in Tangier disease have revealed 50-100-fold increases in cholesterol esters in tonsils (Fredrickson, Altrocchi, Avioli, Goodman, and Goodman, 1961). The relationship between the tissue cholesterol storage and the plasma lipid changes is uncertain (Fredrickson, Levy, and Lees, 1967).

Histological support for a diagnosis of Tangier disease may be desired. However, sometimes the presence of a bleeding disorder as in our case 2, in case 1 of Hoffman and Fredrickson (1965), and in the case of Kummer, Laissue, Spiess, Pflugshaupt, and Bucher (1968) may necessitate caution. The site most likely to give a positive biopsy result would appear to be rectal mucosa, as lipid deposits or yellow patches here have been reported in the five previous patients who underwent proctoscopy, all of whom were adults, and we have now demonstrated this feature in a 5-year-old child. Our necropsy findings in this patient suggest that lymph node biopsy should be equally reliable, even when the nodes are not enlarged. Bone marrow, on the other hand, was negative in our case 1 , and fixed aspirates were negative also in the original two children from Tangier island, although later supravital preparations revealed vacuolated cells (Fredrickson and
Altrocchi, 1962). Jejunal suction biopsy is likely to be negative, as it was in the two cases in which it was performed (Hoffman and Fredrickson, 1965). Necropsy on our case 1 showed that macrophages in the jejunum were limited to the submucosa. In adults with peripheral neuropathy nerve, muscle and skin biopsies have been negative in two cases (Engel, Dorman, Levy, and Fredrickson, 1967) out of three, yet in our case 1 scattered foam cells were found around vessels and nerve in a random block of skin and subcutis.

One possible unrecognized case of Tangier disease, with numerous foam cells in the tonsils of a child who was otherwise well, is illustrated by Ash and Raum (1956), but the information given is inadequate for diagnosis. A likely French case in a 6-year-old girl with 'a specific increase in esterified cholesterol' in tonsils, and absent $\alpha$-lipoprotein, is tabulated without other details (Tanaka, Brecher, and Fredrickson, 1963). The second purported case of these authors had less evidence of Tangier disease.

The only previously reported patient to die (Hoffman and Fredrickson, 1965) was a man aged 48 years who had suffered from 'typical angina pectoris' for five years, and no necropsy was performed. Our case 1 showed focal coronary intimal thickening of uncertain significance at death at the age of 5 years. The two original cases (Fredrickson, Levy, and Lindgren, 1968) and our case 2 have been followed for at least seven years and are alive and well, so that Tangier disease would appear to be a relatively benign condition.

\section{References}

Ash, J. E., and Raum, Muriel (1956). An Atlas of Otolaryngic Pathology, p. 300. American Registry of Pathology.

Destombes, P. (1965). Adénites avec surcharge lipidique, de l'enfant on de l'adulte jeune, observées aux Antilles et au Mali (Quatre observations). Bull. Soc. Path. exot., 58, 1169-1175.

Engel, W. K., Dorman, J. D., Levy, R. I., and Fredrickson, D. S. (1967). Neuropathy in Tangier disease. $\alpha$-lipoprotein deficiency manifesting as familial recurrent neuropathy and intestinal lipid storage. Arch. Neurol. (Chic.), 17, 1-9.

Frederickson, D.S. (1964). The inheritance of high density lipoprotein deficiency (Tangier disease). J. clin. Invest., 43, 228-236.

Frederickson, D. S. (1966). Familial high-density lipoprotein deficiency. Tangier disease. In The Metabolic Basis of Inherited Disease, edited by J. B. Stanbury, J. B. Wyngaarden, and D. S. Fredrickson, 2nd ed. pp. 486-508. McGraw-Hill New York.

Fredrickson, D. S., and Altrocchi, P. H. (1962). Tangier disease (familial cholesterolosis with high density lipoprotein deficiency) In Cerebral Sphingolipidoses. A Symposium on Tay Sachs' Disease and Allied Disorders, pp. 343-357, edited by S. M. Aronson and B. W. Volk. Academic Press, New York and London.

Fredrickson, D. S., Altrocchi, P. H., Avioli, L. V., Goodman, De W. S., and Goodman, H. C. (1961). Tangier disease. Ann. intern. Med., 55, 1016-1031.

Fredrickson, D. S., Levy, R. I., and Lees, R. S. (1967). Fat transport in lipoproteins-an integrated approach to mechanisms and disorders. New Engl. J. Med., 276, 94-103.

Fredrickson, D. S., Levy, R. I., and Lindgren, F. T. (1968). A comparison of heritable abnormal lipoprotein patterns as defined by two different techniques. $J$. clin. Invest., 47, 24462457. 
Gjone, E., and Norum, K. R. (1968). Familial serum cholesterol ester deficiency. Clinical study of a patient with a new syndrome Acta med. scand., 183, 107-112.

Hoffman, H. N. II, and Fredrickson, D. S. (1965). Tangier disease (Familial high density lipoprotein deficiency). Clinical and genetic features in two adults. Amer. J. Med., 39, 582-593.

Holland, P., Hug, G., and Schubert, W. K. (1965). Chronic reticuloendothelial cell storage disease. Amer. J. Dis. Child., 110, 117-124.

Kocen, R. S., Lloyd, June K., Lascelles, P. T., Fosbrooke, Audrey S., and Williams, D. (1967). Familial $\alpha$-lipoprotein deficiency (Tangier disease) with neurological abnormalities. Lancet, 1, 1341-1345.

Kummer, H., Laissue, J., Spiess, H., Pflugshaupt, R., and Bucher, U. (1968). Familiäre Analphalipoproteinämie (Tangier-Krankheit). Schweiz. med. Wschr., 98, 406-412.

Landing, B. H., Silverman, F. N., Craig, J. M., Jacoby, M. D., Lahey, M. E., and Chadwick, D. L. (1964). Familial neurovisceral lipidosis. An analysis of eight cases of a syndrome previously reported as 'Hurler-Variant', 'Pseudo-Hurler Disease', and 'Tay-Sachs Disease with Visceral Involvement'. Amer. J. Dis. Child., 108, 503-522.

Lloyd, June K. (1969). Lipoprotein deficiency disorders. Bristol med.chir. $J ., 84,159-165$

Lough, J., Fawcett, J., and Wiegensberg, B. (1970). Wolman's disease. An electron microscopic, histochemical and biochemical study. Arch. Path., 89, 103-110.

Marie, J., Bernard, J., Nezelof, C., Lévêque, B., Schaison, G. , Desbois, J.-C., Watchi, J. M., and Lemaigre-Voreaux, J. (1966). Adénopathies chroniques avec prolifération réticulo-histiocytaire et surcharge lipidique. Ann. Pédiat., 13, 2689-2697.

Partin, J. C., and Schubert, W. K. (1969). Small intestinal mucosa in cholesterol ester storage disease. Gastroenterology, 57, 542-558.
Rosai, J., and Dorfman, R. F. (1969). Sinus histiocytosis with massive lymphadenopathy. A newly recognised benign clinicopatho- $\widehat{0}$ logical entity. Arch. Path., 87, 63-70.

Schiff, L., Schubert, W. K., McAdams, A. J., Spiegel, E. L., ande O'Donnell, J. F. (1968). Hepatic cholesterol ester storages disease: a familial disorder. 1 . Clinical aspects. Amer. J. Med. 44, 538-546.

Tanaka, Y., Brecher, G., et Frederickson, D. S. (1963). Cellules de $1 a \overline{0}$ maladie de Niemann-Pick et de quelques autres lipoïdoses. $\overline{(})$ Nouv. Rev. frans. Hémat., 3, 5-16.

Wolman, M., Sterk, V. V., Gatt, S., and Frenkel, M. (1961). Primary familial xanthomatosis with involvement and calcification, of the adrenals. Pediatrics, 28, 742-757.

Yunis, E., and Sherman, F. E. (1970). Macrophages of the rectat lamina propria in children. Amer. J. clin. Path., 53, 580-591.

\section{Addendum}

Since this paper was submitted, a further case has been reported by Huth, Kracht, Schoenborn, and.V Fuhrmann (1970) in a 3-year-old girl with enlarged yellow tonsils.

\section{Reference}

Huth, K., Kracht, J., Schoenborn, W., and Fuhrmann, W. (1970). Tangier-Krankheit (Hyp-a-Lipcproteinämie). Dtsch. med.O Wschr., 95, 2357-2361. 